\title{
Protein Content Analysis of Soybean [Glycine Max (L.) Merr.] Lines Results from the Crossing between Detam-2 Varieties with Grobogan
}

\author{
Velda Alysia Halawa ${ }^{1 *}$, Diana Sofia Hanafiah ${ }^{2}$, Mbue Kata Bangun $^{3}$ \\ \{vldahlw03@gmail.com¹,dedek.hanafiah@yaho.co.id²,mkbangun51@gmail.com ${ }^{3}$ \} \\ ${ }^{1,2,3}$ Department of Agrotechnology, Faculty of Agriculture, Universitas Sumatera Utara, Indonesia \\ *vldahlw03@gmail.com
}

\begin{abstract}
Soybean is a plant that is widely used in the food industry and one of the main sources of vegetable protein. The lack of soybean supply in 2016 to 2020 was 1.60 million tons, 1.78 million tons, 1.84 million tons, 1.92 million tons and 1.91 million tons, respectively. Soybean protein content ranges from $35-40 \%$. Protein needs of 55 grams per day can be met with foods derived from 157.14 grams of soybeans. This study aims to determine the protein content of the soybean lines from the crossing varieties of Detam 2 with Grobogan. Based on the research results, it obtained line that has high protein content values, namely F6DxG 50-35-4. Overall, the heritability estimated value for all lines have a high estimated value, which means that the characters observed are genetically inherited.
\end{abstract}

Keywords: soybean lines, protein content analysis, crossing of soybean.

\section{Introduction}

One of legumes that have a very important role is the soybean crop, which is used widely in the food industry and is one of the main sources of vegetable protein [1]. Currently consumer demand for soybean commodity not only in quantity but has led to the quality as well. At some centers in soybean production there has been a shift in consumer preference from soybean-sized seed medium (about $10 \mathrm{~g} / 100$ seeds) into a soybean-sized large seeds ( $>$ $14 \mathrm{~g} / 100$ seeds) and soybeans that have early maturity ( $<80$ days) [2].

Based on projected results, is expected to balance production and consumption of soybean in Indonesia increased deficit in the years 2016 - 2020 average of $36.95 \%$ per year. Soybean supply shortage 2016 and 2020 amounting to 1.60 million tons, 1.78 million tons, 1.84 million tons, 1.92 million tons and 1.91 million tons [3].

Selection is a process of plant breeding and foundation of the entire repair plant to obtain new superior cultivars [4]. Selection of pedigree is one selection in segregating populations aimed at obtaining new varieties by combining desirable genes found in two or more genotypes are expected to produce a derivative better and superior to the parent [5].

Plants that containing intact soy protein content by $35-40 \%$, which is almost equivalent to the protein content of meat. Protein soybean crop is the only one of the types of nuts that has the essential amino acid composition of the most complete [3]. Soy protein requirement of 55 grams per day can be filled with food that comes from 157.14 grams of soy [6]. 
This study aims to determine the protein content of a number of lines of soybean (Glycine max L. Merill) of crossbred varieties detam 2 with Grobogan.

\section{Research Methods}

This research was conducted at tissue culture laboratory and research area of Faculty of Agriculture Universitas Sumatera Utara, Medan. This research was carried out in March to October 2019.

\section{Seed Selection}

The seed used is a seed that has a normal size or no wrinkles and no foul.

\section{Preparation of Land}

The area required for the research first measured in accordance with the requirements, then cleared weeds there. Then formed as a drainage ditch on the land and made a plot with a size of $2.4 \mathrm{mx} 4 \mathrm{~m}$ to 4 plots with $50 \mathrm{~cm}$ distance between plots.

\section{Planting}

Planting is done by making the planting hole at planting area with a depth of $\pm 2 \mathrm{~cm}$, then put one seed per planting hole and then closed again.

\section{Fertilization}

Fertilization is done according to recommended dosage of soybean fertilizer requirements.

\section{Maintenance Plants}

Plant maintenance is watering plants, weeding and maintenance of plants from pests and plant diseases.

\section{Harvest}

Harvesting conducted by picking the pods one by one using hand. Harvesting is done in accordance with the harvesting each crop varieties. Criteria soybean harvest is marked by skin brownish-yellow pods by $95 \%$ and the leaves have fallen.

\section{Analysis of Protein}

Analysis of protein was observed by the method performed by Bradford (1976).

\section{Results and Discussion}

\section{The soy protein content}

F6 plant populations indicates that the amount of the protein content of each line is lower than the varieties Detam- 2 which has a protein content of $45.58 \%$. This is influenced by environmental conditions and requirements grow soybeans states that a high protein content in soy beans led to the need of nutrients nitrogen $(\mathrm{N})$ more, so the availability of $\mathrm{N}$ in infancy is very important to obtain optimal results [7]. 
Table 1. Values F6 protein assay with elders detam DXG and Grobogan along with comparison factor (gram)

\begin{tabular}{lrrrrrrrr}
\hline & detam & Anjasmoro & Grobogan & G5 & G50 & G49 & G13 & G80 \\
\hline sample 1 & 0.37 & 0.54 & 0.47 & 1.07 & 1.57 & 1.04 & 0.74 & 0.87 \\
sample 2 & 0.58 & 0.53 & 1.54 & 0.87 & 1.04 & 0.92 & 1.05 & 0.83 \\
sample 3 & 0.36 & 0.46 & 0.42 & 0.09 & 2.34 & 0.08 & 0.93 & 2.97 \\
sample 4 & 0.38 & 0.07 & 0.73 & 0.81 & 6.78 & 1.01 & 0.84 & 2.87 \\
sample 5 & 0.89 & 0.47 & 0.93 & 0.95 & 0.94 & 0.96 & 0.99 & 0.93 \\
\hline Total & 2.58 & 2.07 & 4.09 & 0.46 & 12.67 & 4.73 & 4.55 & 8.47 \\
Mean & 0.52 & 0.41 & 0.82 & 0.92 & 2.53 & 0.95 & 0.91 & 1.69 \\
\hline
\end{tabular}

The results of the analysis of protein content test showed that the highest levels of the protein contained in the 50 lines contained in the sample 4 . This indicates that the sample 4 line G50 has a clear difference with two parents plus the comparative crops. The important aspect of soy as a source of functional food can be observed from the nutrient content in seeds. On the basis of dry weight, soybeans contain about $40 \%$ protein, $20 \%$ oil, $35 \%$ carbohydrates soluble (sucrose, stachyose, raffinose, etc.) and carbohydrates insoluble (dietary fiber), and $5 \%$ ash [8].

Coefficient of high genetic diversity found in plant height, number of primary branches, number of pods per plant, number of pods contain, the number of seeds and seed weight. KKG high value showed the presence of the genetic and phenotypic diversity that is high so as to facilitate the selection done [9] states that the value of the coefficient of the high diversity in the character - specific code indicates that the selection will be made effective. Characters with high diversity values can be said to have extensive genetic diversity and vice versa.

Table 2. Values Diversity Genetic (KKG) on the Detam X Grobogan (D X G) at F6 generation

\begin{tabular}{|c|c|c|c|c|}
\hline Genotype & Character & $\sigma^{2} \mathrm{~g}$ & $\mathrm{~h}^{2}$ & KKG $(\%)$ \\
\hline \multirow[t]{9}{*}{$\mathrm{F}_{6}$ D X G 50-35-4 } & Flowering age & 0.664 & $0.664(\mathrm{H})$ & $2.144(\mathrm{~L})$ \\
\hline & Plant height & 34.079 & $0.781(\mathrm{H})$ & $16.138(\mathrm{H})$ \\
\hline & $\begin{array}{l}\text { Number of primary } \\
\text { branches }\end{array}$ & 0.438 & $0.572(\mathrm{H})$ & $16.123(\mathrm{H})$ \\
\hline & $\begin{array}{l}\text { Harvest age } \\
\text { number of crop }\end{array}$ & 8.905 & $0.797(\mathrm{H})$ & $2.794(\mathrm{~L})$ \\
\hline & $\begin{array}{l}\text { pods } \\
\text { number of pods }\end{array}$ & 673.288 & $0.998(\mathrm{H})$ & $41.118(\mathrm{H})$ \\
\hline & $\begin{array}{l}\text { contained } \\
\text { number of planting }\end{array}$ & 506.453 & $0.998(\mathrm{H})$ & $52.919(\mathrm{H})$ \\
\hline & $\begin{array}{l}\text { seeds } \\
\text { seed weight of the }\end{array}$ & 1436.110 & $0.998(\mathrm{H})$ & $54.178(\mathrm{H})$ \\
\hline & plant & 21.141 & $0.988(\mathrm{H})$ & $53.540(\mathrm{H})$ \\
\hline & weight of 100 seeds & 0.175 & $0.097(\mathrm{~L})$ & $3.371(\mathrm{~L})$ \\
\hline \multirow[t]{4}{*}{$\mathrm{F}_{6}$ D X G 13-4-1 } & Flowering age & 2.068 & $0.860(\mathrm{H})$ & $3.710(\mathrm{~L})$ \\
\hline & Plant height & 71.526 & $0.882(\mathrm{H})$ & $26.805(\mathrm{H})$ \\
\hline & branches & 0.995 & $0.752(\mathrm{H})$ & $27.810(\mathrm{H})$ \\
\hline & Harvest age & 1.469 & $0.393(\mathrm{M})$ & $1.142(\mathrm{~L})$ \\
\hline
\end{tabular}




\begin{tabular}{|c|c|c|c|c|}
\hline Genotype & Character & $\sigma^{2} \mathrm{~g}$ & $h^{2}$ & $\mathrm{KKG}(\%)$ \\
\hline & $\begin{array}{l}\text { number of crop } \\
\text { pods } \\
\text { number of pods }\end{array}$ & 995.702 & $0.999(\mathrm{H})$ & $52.261(\mathrm{H})$ \\
\hline & $\begin{array}{l}\text { contained } \\
\text { number of planting }\end{array}$ & 562.346 & $0.998(\mathrm{H})$ & $71.044(\mathrm{H})$ \\
\hline & & 1679.697 & $0.999(\mathrm{H})$ & $74.284(\mathrm{H})$ \\
\hline & plant & 24.571 & $0.990(\mathrm{H})$ & $71.244(\mathrm{H})$ \\
\hline & weight of 100 seeds & 2.943 & $0.644(\mathrm{H})$ & $13.585(\mathrm{M})$ \\
\hline \multirow[t]{9}{*}{$\mathrm{F}_{6}$ D X G 5-36-5 } & Flowering age & 3.131 & $0.903(\mathrm{H})$ & $4.597(\mathrm{~L})$ \\
\hline & Plant height & 56.964 & $0.856(\mathrm{H})$ & $20.946(\mathrm{H})$ \\
\hline & $\begin{array}{l}\text { Number of primary } \\
\text { branches }\end{array}$ & 1.406 & $0.811(\mathrm{H})$ & $31.894(\mathrm{H})$ \\
\hline & $\begin{array}{l}\text { Harvest age } \\
\text { number of crop }\end{array}$ & 0.189 & $0.077(\mathrm{~L})$ & $0.411(\mathrm{~L})$ \\
\hline & & 854.944 & $0.999(\mathrm{H})$ & $50.324(\mathrm{H})$ \\
\hline & $\begin{array}{l}\text { contained } \\
\text { number of planting }\end{array}$ & 471.001 & $0.997(\mathrm{H})$ & $66.125(\mathrm{H})$ \\
\hline & $\begin{array}{l}\text { seeds } \\
\text { seed weight of the }\end{array}$ & 1327.021 & $0.998(\mathrm{H})$ & $73.081(\mathrm{H})$ \\
\hline & plant & 20.344 & $0.987(\mathrm{H})$ & $71.073(\mathrm{H})$ \\
\hline & weight of 100 seeds & 1.211 & $0.427(\mathrm{M})$ & $8.547(\mathrm{M})$ \\
\hline \multirow[t]{9}{*}{ F6 D X G 49-19-3 } & Flowering age & 1.424 & $0.809(\mathrm{H})$ & $3.140(\mathrm{~L})$ \\
\hline & Plant height & 66.124 & $0.874(\mathrm{H})$ & $24.105(\mathrm{H})$ \\
\hline & branches & 1.512 & $0.822(\mathrm{H})$ & $30.741(\mathrm{H})$ \\
\hline & $\begin{array}{l}\text { Harvest age } \\
\text { number of crop }\end{array}$ & 0.204 & $0.082(\mathrm{~L})$ & $0.426(\mathrm{~L})$ \\
\hline & $\begin{array}{l}\text { pods } \\
\text { number of pods }\end{array}$ & 1156.319 & $0.999(\mathrm{H})$ & $54.711(\mathrm{H})$ \\
\hline & $\begin{array}{l}\text { contained } \\
\text { number of planting }\end{array}$ & 729.983 & $0.998(\mathrm{H})$ & $77.280(\mathrm{H})$ \\
\hline & $\begin{array}{l}\text { seeds } \\
\text { seed weight of the }\end{array}$ & 2003.609 & $0.999(\mathrm{H})$ & $79.332(\mathrm{H})$ \\
\hline & plant & 33.108 & $0.992(\mathrm{H})$ & $77.004(\mathrm{H})$ \\
\hline & weight of 100 seeds & 16.522 & $0.910(\mathrm{H})$ & $30.014(\mathrm{H})$ \\
\hline \multirow[t]{7}{*}{$\mathrm{F}_{6}$ D X G 80-48-3 } & Flowering age & 0.958 & $0.740(\mathrm{H})$ & $2.531(\mathrm{~L})$ \\
\hline & Plant height & 93.187 & $0.907(\mathrm{H})$ & $28.730(\mathrm{H})$ \\
\hline & $\begin{array}{l}\text { Number of primary } \\
\text { branches }\end{array}$ & 1.584 & $0.828(\mathrm{H})$ & $35.956(\mathrm{H})$ \\
\hline & $\begin{array}{l}\text { Harvest age } \\
\text { number of crop }\end{array}$ & -0.793 & $-0.537(\mathrm{M})$ & $0.000(\mathrm{~L})$ \\
\hline & $\begin{array}{l}\text { pods } \\
\text { number of pods }\end{array}$ & 1096.574 & $0.999(\mathrm{H})$ & $54.485(\mathrm{H})$ \\
\hline & contained & 592.761 & $0.998(\mathrm{H})$ & $74.658(\mathrm{H})$ \\
\hline & number of planting & 1904.685 & $0.999(\mathrm{H})$ & $80.160(\mathrm{H})$ \\
\hline
\end{tabular}




\begin{tabular}{rlccc}
\hline Genotype & \multicolumn{1}{c}{ Character } & $\sigma^{2} \mathrm{~g}$ & $\mathrm{~h}^{2}$ & KKG $(\%)$ \\
\hline & & & & \\
& seeds & & & \\
& seed weight of the & 30.846 & $0.992(\mathrm{H})$ & $87.128(\mathrm{H})$ \\
& weight of 100 seeds & 0.742 & $0.313(\mathrm{M})$ & $7.427(\mathrm{M})$ \\
\hline Information: $H=$ High, $M=$ Medium, $L=$ Low & & &
\end{tabular}

In F6 plant populations showed that the character that has the highest diversity of parameters contained in plant height, number of primary branches, number of pods cropping, pods contain, the number of crop seeds and planting seed weight. Characters that have low diversity values contained in the parameter flowering date and time of harvest, and the characters have a value of genetic diversity that are contained in the 100 -seed weight parameters. Coefficient of high diversity in the character - specific code indicates that the selection will be made effective. Characters with high diversity values can be said to have extensive genetic diversity and vice versa. Extensive genetic diversity indicates a more dominant genetic influence than the environmental effects [9].

Extensive genetic diversity can provide an opportunity for breeders to be able to make the selection. Selection is a process of plant breeding and foundation of the entire repair plant to obtain new superior cultivars. The success of the selection depends on the ability of breeders to separate the superior genotypes of unwanted genotypes [10].

\section{Conclusions}

Based on the research results obtained, lines that have a high protein content value, namely F6 D x G 50-34-5 compared to other lines. Overall, the heritability estimated value for all lines have a high estimated value, which means that the characters observed are genetically inherited.

\section{References}

[1] Yuniaty, A. Genetic Variations of Soybean Genotypes in Drought Stress Conditions. Jenderal Soedirman University. Purwokerto (2013)

[2] Krisdiana, R. Distribution of Soybean Superior Varieties and Their Impact on the Rural Economy. J Food Crop Agricultural Research 33 (1): 61-69 (2014).

[3] Nuryati, L., Budi, W., Roch, W. Outlook on Agricultural Commodities for Soybean Food Crops. Center for Agricultural Data and Information Systems Ministry of Agriculture 2016. ISSN: 1907 - 1507 (2016)

[4] Barmawi, M. The Pattern of Segregation and Heritability of the Soybean Resistance Characteristics of the Cowpea Mild Mattle Virus Wilis X MLG Population 251. J. HPT Trop. 7 (1): 48-52 (2007)

[5] Syukur, M. 2005. Estimation of Genetic Parameters in Plants. Bogor Agricultural Institute. Bogor. (2005). 
[6] Septi Winarsih, Atik, Ratminto. Service Management. Yogyakarta: Student Library (2012).

[7] Salvagiotti, F., K.G. Cassman, J.E. Specht, D.T. Walters, A. Weiss, A. Dobermann. Nitrogen absorption, fixation, and response to $N$ fertilizer in soybeans: a Review. Field Crops Res. 19 p. (2008).

[8] Gilbert, E.R.., D. Liu. Anti-diabetic function of soybean isoflavone genistein: mechanism of effect that underlies the function of pancreatic cells. Food \& Function 4 (2): 200-212 (2013).

[9] Ochola, G., Tusiime, G. Pathogenicity of the rice yellow spot virus and a source of potential resistance to disease in Eastern Uganda. Asian Journal of Plant Pathology 5 (1): 1-15 (2011).

[10] Anshori, M, Djoko Martono. Biology X for high school \& MA. Jakarta: Bookkeeping Center of the Ministry of National Education (2009).

[11] Nino-Liu, D.O., Ronald, P.C., Bogdanove, A.J. Xanthomonas oryzae pathovars: pathogenic models of plant models. Mol. Plant pathol. 7 (5): 303-324 (2006). 